\title{
URBAN AND HYDROGEOLOGICAL ALERT ON THE MORPHOCLIMATIC RISK AFFECTING QUITO'S WORLD HERITAGE
}

\author{
P. Bracchi ${ }^{1, *}$, F.J Torrijo ${ }^{2}$, A. Boix ${ }^{1}$, M. Cruz Cabrera ${ }^{1}$, D. Giordanelli ${ }^{1}$ \\ ${ }^{1}$ Facultad de Arquitectura y Urbanismo, Universidad UTE de Quito - (paola.bracchi, alberto.boix, marianela.cruz, dario.giordanelli) \\ @ute.edu.ec \\ 2 Departamento de Ingeniería del Terreno, Universitat Politècnica de València - fratorec@trr.upv.es
}

Commission II - WG II/8

KEY WORDS: Natural Risk, Ravines, Quito, Heritage, Memory

\begin{abstract}
:
The ecological risk attached to the filling of Quito's ravines, together with the subsequent loss of a memory about their existence, are the focus of this paper which aims to provide a base for both comprehension and action. Ravines are part of the geomorphology of the city's basin and play a vital role in the hydrogeological system of Quito's water cycle. They have been filled over time, disappearing from urban maps. This disrupts ravines' original course and natural drainage system generating risks. An integral multi-scale perspective that considers geomorphological and hydrogeological modifications is missing. Three problematics can be observed. Technical-infrastructural, Urban-spatial and Architectural-cultural. The conjugation of all the phenomena described above, constitutes a call to consciously establish the risk level to which this territory is exposed. The damage goes beyond material or human loss. It affects history, living memory, identity, and knowledge. All these aspects have contributed to the consideration of HCQ (Historical Centre of Quito) as World Heritage Site. These are valuable legacies that need to be preserved. Therefore, it is necessary to undertake a detailed inventory of: i) the technical constructive state of patrimonial buildings made using raw earth; ii) the modifications and current state of DMQ's (Metropolitan District of Quito) ravines; iii) the existing interstitial spaces associated to the ravines' path within the HCQ. The paradigm under consideration for the future is not conservation but integral protection. Rescuing Memory in relation to HCQ's ravines as an active operator for transformative provisions associated to social, environmental, urban and architectonic dimensions becomes fundamental for future development.
\end{abstract}

\section{INTRODUCTION}

The ecological risk attached to the filling of Quito's ravines, together with the subsequent loss of a memory about their existence, are the focus of this paper which aims at providing a base for both comprehension and action. Ravines structure the functioning and environmental balance of the city. They are part of a reality which exposes issues produced by the response to technical-infrastructural matters, reflected in urban-spatial and architectural-cultural aspects. If these issues are not urgently taken into consideration, the greatest risk observed in this study is the loss of the built heritage of Quito (UNESCO World Heritage Site since 1978).

Ravines are part of the geomorphology of the city's basin and play a vital role in the hydrogeological system of Quito's water cycle. They have been filled over time, disappearing from urban maps. This disrupts the ravines' original course and natural drainage system generating risks. Quito is particularly exposed to a wide variety of natural risks given its location and its spatial development, including seismic, volcanic (Pichincha, Cotopaxi) and morphoclimatic risks, such as landslides, sliding, avalanches, mudflows and flooding (Sierra, 1997). Following the objectives of this paper we concentrate in the existing relationship between morphoclimatic risk affecting Quito's built heritage and the filling of ravines.
From a general depiction of the city and the Historic Centre of Quito (HCQ) as World Heritage Site, the paper analysis the issues brought about by the filling of ravines in the HCQ. We consider two related problematics (hydrogeological and urban) which are seen as the base for the architectural-cultural problematic. HCQ is an admirable context of architectural quality. The colonial buildings were made according to the Hispanic model of a patio house, adapted through local construction modalities, such as the use of raw earth techniques. Among these, adobe-based methods, the use of rammed earth for walls and wood for the structural system were frequent. Many monumental buildings also present large adobe walls supported by continuous stone foundations. Nowadays we can see that more than $50 \%$ of central buildings continue to have a raw earth structure. Quito's built heritage has always been looked after from an architectural perspective. Nevertheless, the current morphoclimatic risk, which incorporates hydrogeological and urban issues on a territorial scale, implies a much larger threat.

As Corboz (1983) points out: land is not a piece of information, but rather the result of several processes. Therefore, it is possible to state that this local amnesia on ravines is a land of oblivion, which does not follow pre-existing geological systems but rather develops against them. The sad fate of this titanic and impossible struggle is the wait for the breaking point. This risk condition determines a fragile city which seems to remain in a brutal, announced fatalism.

\footnotetext{
* Corresponding author
} 


\section{THE SITE. QUITO AND THE RAVINES}

\subsection{General profile}

San Francisco de Quito is one of the oldest cities in Latin America. It is the capital and the political, cultural and financial centre of the Republic of Ecuador. It is located at an average height of 2850 m.a.s.l. in the Andes range, more accurately within the Guayllabamba valley, in the Inter-Andean Alley plateau which separates the eastern and western sides of the Andean range. The city's western end is defined by the eastern slopes of the active Pichincha volcano, which dominates the urban extension in such way that its hillsides are visible from any angle, shaping the city's sectors. This geographical condition gives the city its peculiar elongated pattern, with 50 $\mathrm{km}$ in length and averaging 3 to $7 \mathrm{~km}$ in width, traversed by more than 100 ravines from east to west. The city, located about $25 \mathrm{~km}$ north of Quito's old town, is crossed by the equator, which produces significant landscape diversity.

Enclosed within colonial borders until the $20^{\text {th }}$ century, Quito experiences an important population explosion fairly fast. While in 1902 the city took up 200 hectares of land, this number increased to 1300 hectares in 1950 and currently the whole Distrito Metropolitano (which includes the city and its surroundings) has an area of 290746 hectares. Urbanised land has an area of 43116 hectares. From the second half of the $20^{\text {th }}$ century until now the size of Quito has grown tenfold, with a significant acceleration in the last decade. Its urban population reached 1.98 million people according to the latest census.
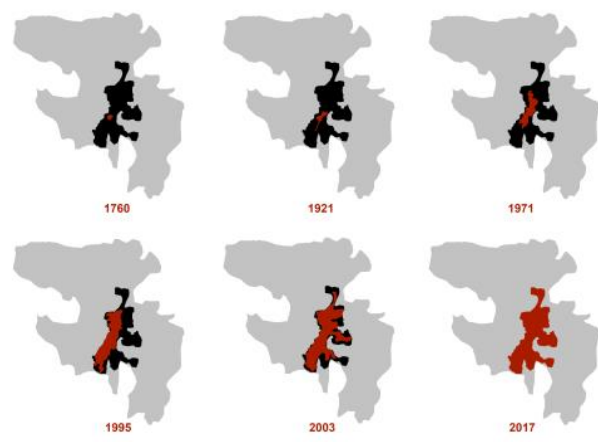

Figure 1. Quito urban growth. Credits: Paola Bracchi.

The colonial town was founded above the pre-Columbian city on 6th December 1534 by Sebastián de Benalcázar and it became the country's capital in 1830. Within its urban area, the Historic Centre stands out, declared World Heritage Site by Unesco in 1978. The monumental appearance of its great buildings, but especially the multiple cultural aspects contained at the architectural, artistic and landscape levels, ratified the exceptional universal value of this location.

Quito's Historic Centre, located south of the city centre, has an area of 375 hectares. It can be considered a complex location where great social, spatial, environmental and cultural diversity co-exists. It is defined by a consolidated and unique patrimonial, touristic, socio-administrative and commercial dimension. QHC has 14 neighbourhoods and is considered Latin America's best-preserved historic site and one the most important in the whole region. It contains around 130 monumental buildings and more than 5000 placements registered as historic sites (Empresa Pública Metropolitana de Gestión de Destino Turístico, 2011).
The reticulated urban layout, typical of a colonial town, is based in the urban reticular structure inspired by the Roman castrum. The regular checkerboard was adapted to the site's topography, where necessary adjustments were made not so much due to mountain hillsides but mostly because of the presence of ravines. HQC is the meeting point par excellence due both to its central location - which makes it a city's focal point - and its sum of time into the past (Empresa Pública Metropolitana de Gestión de Destino Turístico, 2011) which allows it to acquire a historical value. Because of a double quality of space (centrality) on the one hand and temporality (history) on the other, it is the meeting point of a population that inhabits spaces which surpass them (trans-territoriality) and it is also the sphere where different societies - from different times and historical moments (trans-temporality) - meet. This condition provides the Historic Centre with the particular symbiotic quality of spatial, time and patrimonial plurality (Carrión, 2009).

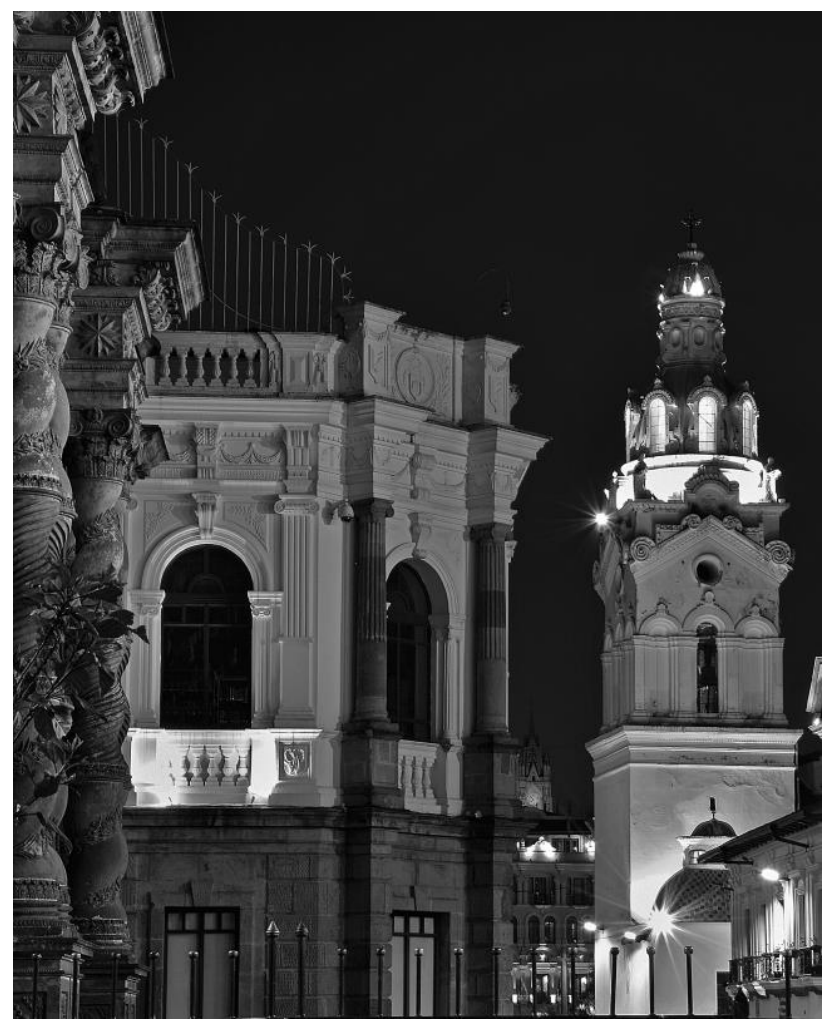

Figure 2. Quito built-up heritage. Photo by Paola Bracchi.

\subsection{Geological Framework}

The most important geological trait of the Inter Andean Central Valley is the Active Quito Fault System. Its morphological depiction is defined by a group of three hills which, without being connected, keep a common orientation (N-NNE) (Villagómez, 2002).

As a consequence of this tectonic system, the Inter Andean Central Valley is divided in three basins, each of which manages individually its own sedimentary processes. These three sub-basins are Quito, San Antonio and Guayllabama. The one studied in this paper is the Quito sub-basin and is found between the western Andean range (Complejo Volcánico Pichincha) and the Batán - La Bota fault. The intense rain and wind erosion modified the existing geomorphological units, producing canyons and very steep slopes. 
The eastern slope of Pichincha and the block raised by Quito's fault (where the city is built) are made of lava, hardened limestone and volcanic deposits covered almost evenly by a layer of 10-20 metres thick of slimy volcanic ash. The lithological formations present the singularity of opposing little resistance to fluvial erosion, giving way to a network of ravines that cross through the entire urban location (Peltre, 1989).

2.2.1 Climate: Quito has a high elevation subtropical climate. Three sectors can be observed within the city. The southern sector, located at higher altitude and with lower temperatures. The central sector, on the other hand, is the warmest. The northern sector presents the mildest climate.

Data from the National Institue of Meteorology and Hydrology (INAMHI, 2015) shows that between 2000 and 2012, the average temperature is roughly $15^{\circ} \mathrm{C}$. Regarding maximum temperatures, the average is roughly $22^{\circ} \mathrm{C}$, with highs of up to $30^{\circ} \mathrm{C}$ in dry months (June, July and August). In terms of minimum temperatures, annual average oscillates between $8^{\circ} \mathrm{C}$ and $10^{\circ} \mathrm{C}$, reaching night lows of $4^{\circ} \mathrm{C}$ or $5^{\circ} \mathrm{C}$.

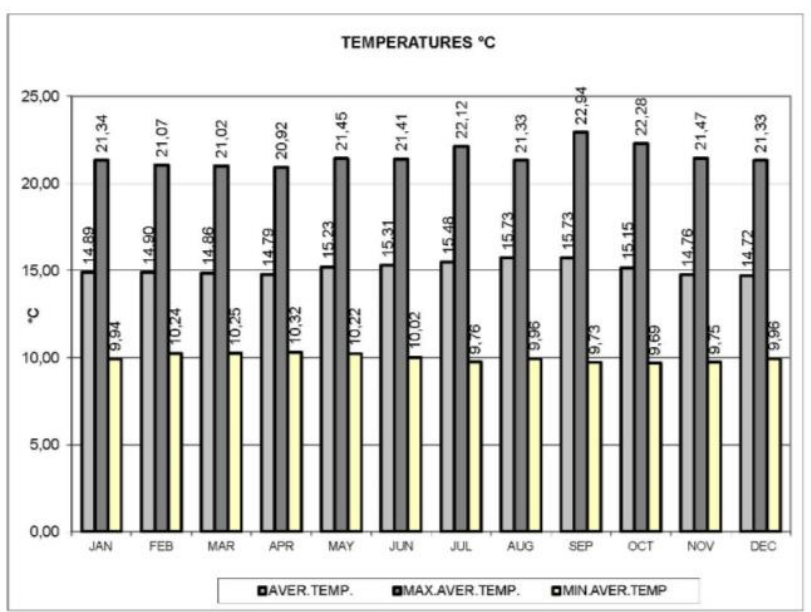

Table 1. Average temperature 2000-2012, INAMHI.

2.2.2 Pluviometry: In order to talk about Quito's pluviometry, we have to differentiate two well defined seasons. The dry season, including June, July, August and September. And the humid season where the remaining months are found, with peaks in April and November.

According to data from INAMHI, between 2000 and 2012, March and April were the rainiest months with average values ranging between $140 \mathrm{~mm}$ and $196 \mathrm{~mm}$, and August is the driest month with average rainfall values that reach a meagre $15 \mathrm{~mm}$.

The differentiation between the south/central region and the north region of the city should be noted regarding rainfall. As Peltre (1989) points out, "the Pichinca volcano protects the north of the city from the incoming humid air masses from south-west. In addition, the effects of dry and warm winds flowing down through the Guayllabamba basin, which strongly diminishes the concentration of atmospheric humidity in the northern part of the city and in the Perucho, Guayllabamba and San Antonio sectors. The intensity of rainfalls, despite not very voluminous in absolute terms, allows fairly strong drippings in the steep slopes.

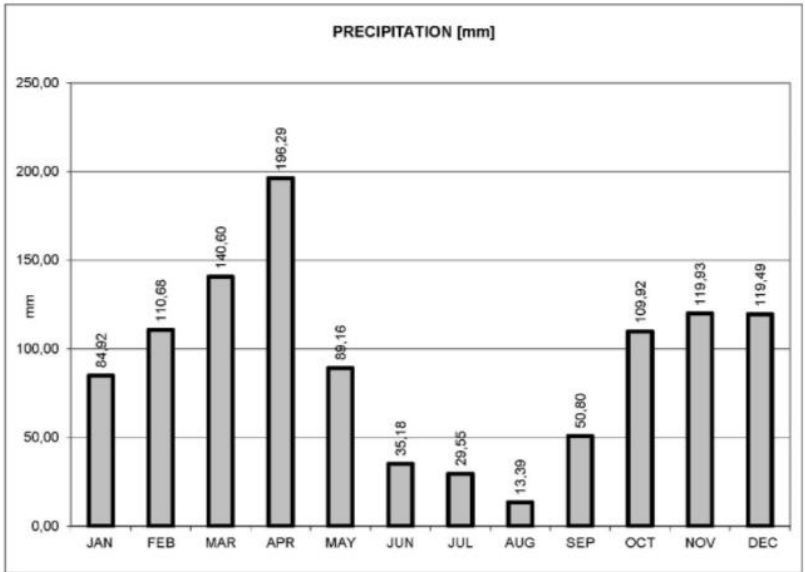

Table 2. Average rainfall 2000-2012, INAMHI.

The geological and hydrometeorological traits mentioned above corroborate the fragile ground condition of Quito's basin. The HCQ is specifically affected by anthropization. Within this research, close attention is paid to the closure of ravines, the layout of the drainage system and the urban boomb which influence the oversaturation of the ground at various levels. All these factors increase the fragility and risk to which Heritage is exposed.

\subsection{Ravines of Quito}

From the slopes of the Pichincha volcano and other mountainous formations along the western end "an intense web of ravines passes through the entire urban site" (Peltre, 1989). It is a system of intermittently-formed rivers that rhythmically go through the city's plain from east to west. These ravines can reach 15-20 metres of depth with steep edge and strong slopes (20-30 degrees). They constitute an important natural drainage network which has been modified over time to favour the city's growth. According to current urban development there are more than 120 ravines, many of which have been filled up.

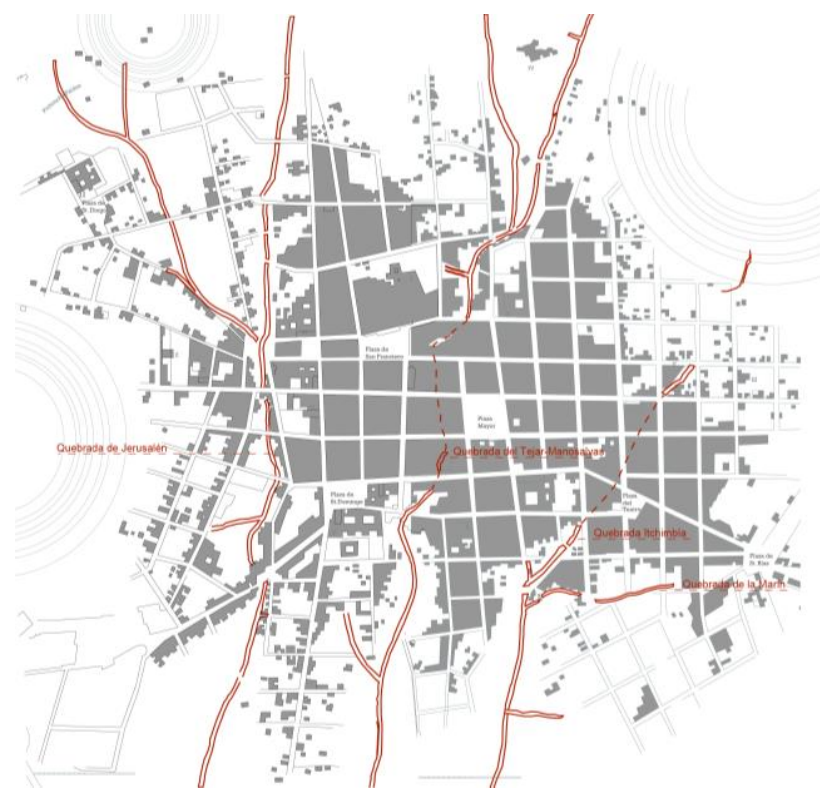

Figure 3. Quito's ravine in relation with the ancient urban fabric of the historical city centre. Credits: Paola Bracchi. 
As previously stated, initially the urban fabric of $\mathrm{HQC}$ - before the fillings - was adapted to the presence of ravines which made their way down from the eastern slope of the Pichincha volcano down to the Machángara river. The historical maps provide evidence for the existence of four main ravines. The first one, the Jerusalén ravine, defined the southern rim of the city and it coincides with current 24 de Mayo Street. The second one, Tejar or Manosalvas ravine/s, crossed the central part of HQC which is completely covered by the urban fabric today. The third one, the Ichimbía or Pilishuaico ravine, crossed through the northern end of the historic centre. It also runs below the urban fabric and borders the current theatre square. The fourth one, the Marín ravine, is a ravine of smaller size which marks the eastern end between the historical centre and the Itchimbía hill.

It is important to point out that none of these ravines is currently visible within the HQC perimeter. The process of urban growth and the need to answer technical and infrastructural questions of fabric continuation, fulfilment of direct connections and water channelling, determined the gradual filling of the ravines.

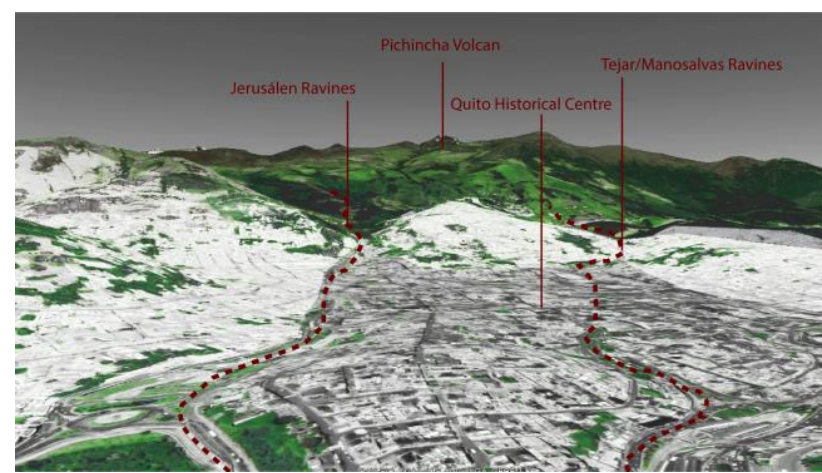

Figure 4. Quito's ravine in relation with the contemporary urban fabric of the historical city centre. Credits: Paola Bracchi.

From the $18^{\text {th }}$ century onwards, the ravines began to be closed in a fragmented and discontinuous manner according to particular interests. This phenomenon became symptomatic and recurrent when the city began to grow consistently outside the limits of the colonial model, that is, from the 20th century onwards.

\section{PROBLEMATIC OF THE HCQ}

\subsection{General problematic}

In 2011, UNESCO's Recommendation on the Historic Urban Landscape was adopted, which established that this kind of landscape includes the site's morphology, geomorphology, hydrology and natural features; its built environment, whether historic or contemporary; its infrastructures both above and below ground; its "open spaces" and gardens, its "land use patterns" and "spatial organization"; perceptions and visual relationships; and all other elements of "urban structure". It includes social, cultural and economic practices and values, and immaterial dimensions of heritage, diversity and identity (UNESCO, 2011). Geography (uneven topography and presence of great ravines) in the context of HCQ plays a significant role in its spatial configuration and also in its transformation and conservation over time.
HCQ has been the object of multiple interventions ${ }^{1}$ over more than 20 years, including several aims such as: conservation and rehabilitation of HCQ's heritage, improvement of living conditions, revitalisation of commercial activity and traditional services, land use heterogeneity and residential development. More recently, touristic management and development has been given a major role as a key engine for the area's future development (Cruz Cabrera, 2017). Despite concerns about built heritage and its preservation, and prioritisation of touristic activity, the landscape associated with its peculiar geography has not been addressed enough. Recovering the values of urban historic landscapes translates into better habitats and living conditions for people.

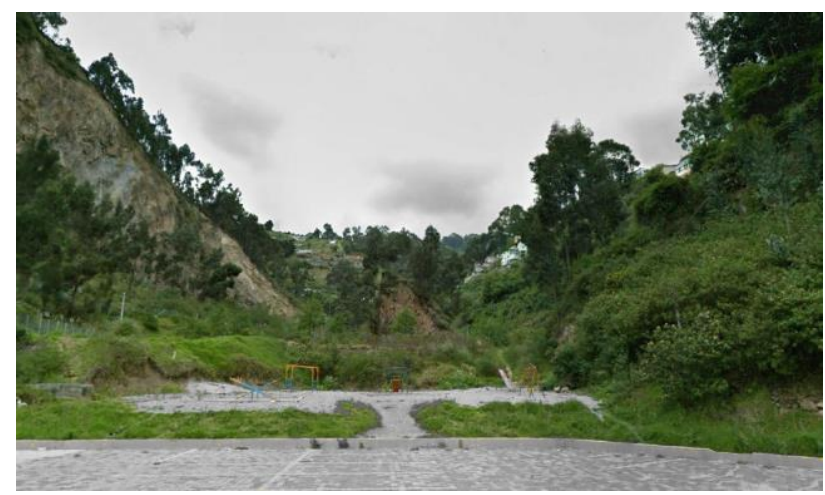

Figure 5. Closer point of Jerusalén ravine.

It is important to point out that towards the end of 2018 Quito's Council, together with the UNESCO office in Quito and the Metropolitan Institute of Heritage presented the 'Disaster Risk Management Plan for the Historic Centre of Quito" (MDMQ., UNESCO., 2018). The document has the objective of proposing strategies to reduce the risks to which patrimonial goods are exposed in the face of natural disasters (seismic risk, volcanic eruptions, earthquakes, flooding and fires). Although the document provided a detailed analysis about monumental buildings in the centre of HCQ, some doubts remain regarding the level of focus sought. The document measures the risk of each building within the perimeter of the city centre, and does not operate based on relationship between territorial-urban risk on all of the HCQ, but rather focuses on specific cases. Even if it encourages an integral vision between risk typologies, it leaves out an integral multi-scale perspective that would consider geomorphological and hydrogeological modifications that the city has had over time, and which can be considered the pillar of morphoclimatic risk.

This premise, in relation with the closure of HCQ's ravines allows the identification of three emerging and co-related problematics which provide a base for this paper's objective

\subsection{First Problematic. Technical/Infrastructural}

The first drainage system in Quito began construction in 1905, with the water discharge network placed in the ravines. The first sewer pipe built was located in the Jerusalén ravine, followed by those of Sucre and Manasalvas (found in the Tejar and the Manosalvas ravines). The Tejar sewer pipe was built along the Tejar ravine and connects with the Itchimbía ravine.

\footnotetext{
Plan Maestro de Rehabilitación Integral para las Zonas Históricas de Quito (1991); ii) Plan de Rehabilitación del Centro Histórico-BID 1ra fase (1994); iii) Plan Especial del Centro Histórico (2003): iv) Plan Q (2003); v) Plan de Rehabilitación del Centro Histórico-BID 2da fase (2004); v) Plan Q 2012.
} 
In the beginning of the 20th century, the widespread conception of ravines was that they served only as evacuation systems for used wastewater, rainwater and trash. Environmental issues, such as the reduction of natural drainage these actions entail (Hazen \& Sawyer, 2011), were not reflected upon then. Hazen and Sawyer's report on EPMAPS, together with other relevant documents, confirm that the sewage system, even if partially fixed, continues to be the same than in 1900 and still works as initially conceived: through a combined form. That means, both rainwater and wastewater (disposal water from human activity) run through the same pipes (Hazen \& Sawyer, 2011).

The state of the sewage system reveals important issues:

1. Sewer pipe combined usage and capacity. The diameter of pipes used in the early 20th century does not respond to the increase of fluid volume generated by larger population and higher torrential rain intensity due to climate change. Moreover, bottle neck conditions in joints create pressure flows. This phenomenon worsens during rainfall season as the combined system overloads and leads to flooding.

Within the HCQ sewer pipe system improvements have taken place, although the latest catastrophic events (HQC March 2019 flooding) show that the issue is on-going.

2. Obsolescence. Many pipes remain the same than in the beginning of the 20th century. The old sewer pipes have varied forms, made through composite construction (stone, brick and concrete) and present holes and infiltrations. There are quick obsolescence processes in more recent pipes due to lack of maintenance, sediment accumulation and construction defects.

3. Underground dripping. The joining of sewer pipes is often done in forced angles and at great speed, leading to hydraulic singularities which damage the sewer pipes (Hazen \& Sawyer, 2011). This is observed at the contact point between the slopes and the plain, exhibiting underground dripping parallel to the sewer pipes (Peltre, 1998). Unstable filled soil can reveal underground erosion which can lead to street sinking, as it happened with the sinking of Vial del Trebol in 2008 and the recent street sinking between the Amazonas and Naciones Unidas avenues (21 January 2020).

4. Torrential lava/mud flows. At times of intense torrential rain, the generated flows above the ravines can bring up soil and mud which block the pipes. These flows seek other routes towards the lower plain and along the streets, knocking down what they find in the way (mud flow in Barrio del Pinar Alto, March 2019).

The development of the combined evacuation network of ravine waters has contributed to the disappearance of the site's natural drainage. The filling of ravines generates flooding, underground dripping, sinking, mud flow and torrential lava. These are catastrophic phenomena which threaten the city in general and the heritage of HCQ in particular.

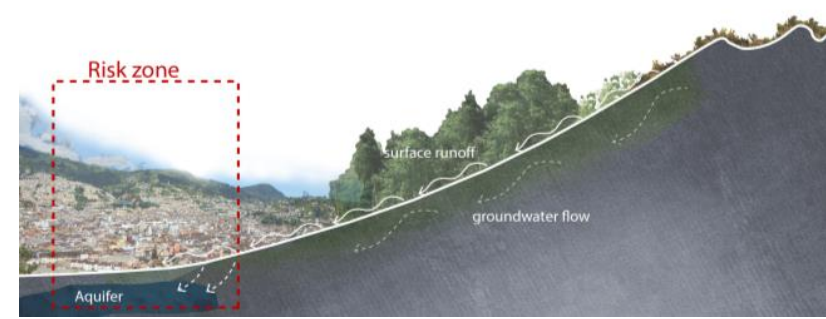

Figure 6. Pichincha slope water system facing with the valley. Surface runoff and Groundwater flow.

\subsection{Second Problematic. Urban/Spatial}

Urban-spatial issues contribute to the disappearance of the city's natural drainage. Modifications to the squared block model used originally in the colonial city were made with the objective of allowing the passing of water streams. The conquerors did not respect the presence of ravines for their environmental role, but because the fluvial pathways were used as dumping sites, which could get rid of urban trash using water power. The environmental role of water drainage is not considered during rainy periods.

The need to respond to such phenomenon of accelerated and invasive growth through the north-south spectrum, but also along the valley's slopes, has led to decisions being made on the basis of urgency rather than on structured and integrated thinking of the city. A radical change in the relationship with the natural context took place: the ravines, seen as elements which prevent fast growth, instead of being interpreted as systems of environmental framing for urban development, were literally erased from maps. The geographical memory of a millenary past was voluntarily removed from the decisionmaking processes on the city's urban development.

In the specific case of HCQ the relationship between ravines and urban growth was revealed through two recognisable tendencies found in maps, endorsed by the political powers of the time.

1. The ravines have been filled for the production of road axes. The first public construction work efforts by the Cabildo de Quito in the late 16th century consist of a system of beam bridges which crossed over the ravines, so as to give streets continuity at some points of the original checkerboard. As the city centre expanded and external relations intensified, the bridge system was not enough. In early 20th century the Jerusalén ravine was closed along its east-west spectrum (within the limits of HCQ) to provide a road axis which marks the south end of HCQ and the beginning of Panecillo hill. In 1922 the 24 de Mayo Boulevard is opened. This road, based on Haussmann's work in Paris, was considered the widest and most modern in the city (Ortiz Crespo, 2004).

The city's first regulatory plan came about in 1944, inspired by maps of European origin which foresaw great axes for wheeled transport. It is in these dates that the avenue Pichincha is realized, that it breaks carelessly in the historical centre and it extends on the filled ravines of Itchimbía and La Marín. Sucre street expanded towards the south above the filled Manosalvas ravine. These two streets, which follow the original ravine's paths, flow into a major transport intersection in HCQ, the Marín bus station. 


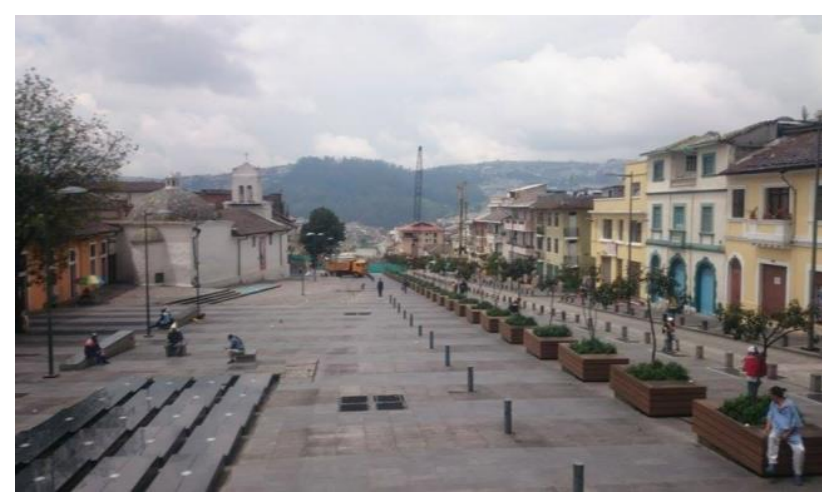

Figure 7. 24 de Mayo Boulevard realized above the Jerusalén ravine. Photo by Marianela Cruz.

In the early 70's the latest transformations of the historic path took place, which also modified the relationship with the ravines' natural system, creating significant problems in built-up spaces. At HCQ's eastern rim the San Juan tunnels were built. The great displacements needed to create these underground road systems, caused structural damage to La Merced church and several other buildings in San Diego's neighbourhood. Furthermore, this underground system also breaks up the natural relationship with the ravines and is subject to great flooding during rainy season.

2. The ravines have been filled as a consequence of the increasing price of land. Towards the end of the 16th century, Quito experiences a population rise. This rise determines the expansion of the original colonial town. It also defines the willingness of central land-owners to sell their land at good prices. These reasons explain why the Historic Centre's ravines have been filled in a fragmented manner and with no planning. This is obvious at the Tejar/Manosalvas ravine, where various owners had the chance to engage in fillings around the Plaza Mayor with their own money. This became the norm over time, and anyone with enough funds could fill up the part of the ravine within its property area in order to increase buildable space. This is exactly what was found with the Jesuits. Under the Compañía de Jesús church the Tejar/Manosalvas ravine flows. Some excavations undertaken for maintenance have revealed the system of cementation used with an ancient Roman technique known as sostruzione.

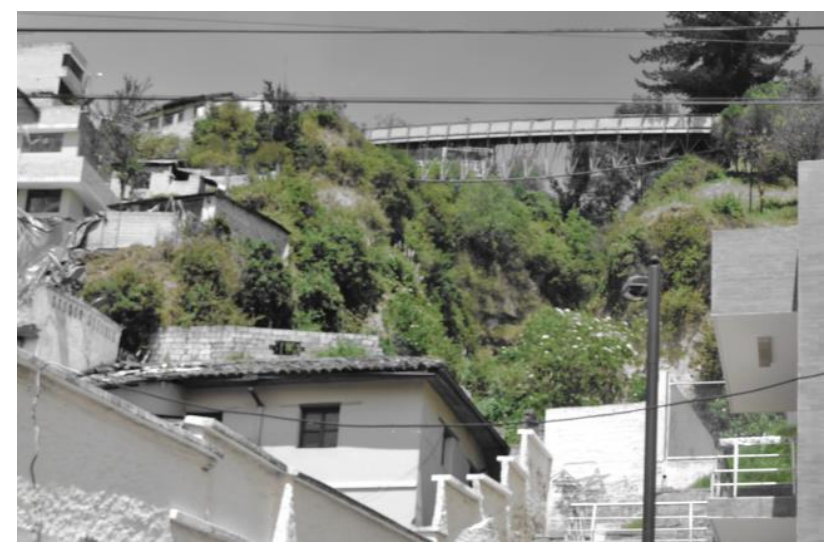

Figure 8. Contemporary condition: constructions above the Itchimbía ravine. San Juan slope. Photo by Marianela Cruz.

\subsection{Third problematic. Architectural-cultural}

A building is the visible element on which the aforementioned issues, described with an obvious intensity, take form. We need to consider that this object also provides the tangible value required for the territory to be considered World Heritage Site. It seems important to state that neither the technicalinfrastructural nor the urban-spatial problematics manifest in a direct manner, but rather generate effects to the surrounding context, which in HCQ's case are seen in built spaces.

It seems necessary to identify the issues that characterize HCQ's buildings, as previous research suggests that $50 \%$ of them are built on raw earth - adobe and rammed earth or taipa. Research also suggests that these buildings are affected by capillary moisture, which originates in the ground conditions on which they are constructed.

We can identify the actions of four particular phenomena which impact these buildings:

1. Time. From the 16th century, buildings have been constructed according to local techniques, that is, with raw earth - adobe and taipa. Over time, this construction technique endured and with the gradual appearance of new materials some exceptional work begins to make use of concrete and steel. Some buildings made with traditional materials were supported with steel and concrete structures, which given their resistance and behaviour, rather than being of help actually caused damage instead.

2. Ground conditions. The ground is subject to tensions due to the geological configuration and water saturation caused by the filling of ravines, drainage inefficiency and network obsolescence.

3. Human action. Human activity was often undertaken in an improvised manner and without adequate techniques. Intervention on built spaces lacked control. At HCQ high commercial activity has significantly changed the built-up fabric. The facades of many buildings were kept, but behind many modifications were done in an uncontrolled manner.

4. Hydrometeorological events. The territory is under constant threats of seisms, volcanic eruptions, torrential rains, flooding and sinking. Furthermore, seismic risk, despite not having its epicentre inside the studied area, is considered a relevant threat as it can significantly damage buildings whose structures and stability are already affected due to humidity. Finally, it must be pointed out that morphoclimatic risk is the main danger affecting built heritage. Recurring pathologies are detected in buildings, such as capillary moisture, which make buildings vulnerable to structural damage and differential settlement. These gradually affect the entire building and threat their stability and permanence. It must be stressed out that these pathologies are discovered as a consequence of the filling of ravines. 


\section{CLOSING}

RAVINES

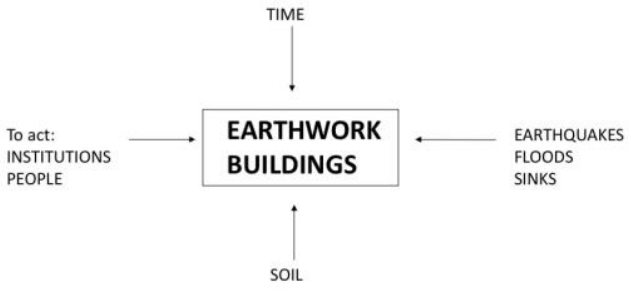

Figure 9. Relation between Ravines filling and built-up heritage. Credits: Dario Giordanelli.

The conjugation of all the phenomena described above, worsened by the frequent threat of hydrometeorological activity, constitutes a warning to consciously establish the risk level to which this valuable territory is exposed. The damage goes beyond material or human loss. It reaches the history, living memory, identity, knowledge (of technical and construction processes). These are valuable legacies that need to be preserved.

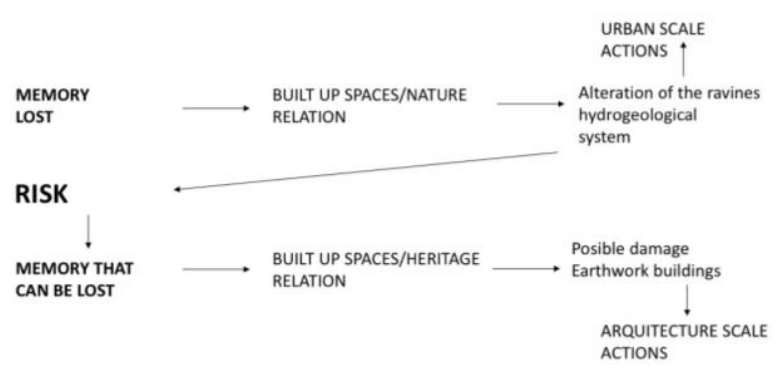

Figure 10. Relation between the loss of memory and risk. Credits: Dario Giordanelli.

\section{CONCLUSIONS}

This paper reveals the high level of risk to which HCQ is exposed. The permanence and preservation of this valuable area of Quito are of paramount importance. The filling of its ravines has led to the worsening of several issues over time. At an environmental level, its natural course, water cycle, vegetation and urban fauna are affected. Regarding infrastructure, the functioning of its drainage and sewage systems is also exposed. On the architectural front, buildings - their walls, foundations are affected by humidity conditions which endanger their durability.

Two different dynamics related to memory are also exemplified: (i) A lost memory of the hydrogeological system of ravines and (ii) a memory at risk of being lost, that of raw earth buildings inside the HCQ. Both involve material and immaterial components related to urban and architectural issues.

In Quito, the restoration process for historical buildings is based on an architectural perspective, without taking into account the high hydrogeological risk that threatens the Historic Centre. The urban and architectonic scales need to be considered simultaneously. Otherwise the risk of memory loss understood as the disappearance of the ancestral relationship between the territory and the ravine system - can provoke irreversible damage in buildings. Morphoclimatic risk, in the form of flooding or landslides, becomes a real threat in the context of a clogged-up system that lacks adequate draining in filled ravines. Conservative interventions at the architectural level alone cannot reduce the level of risk affecting heritage at an urban scale. An intervention is considered necessary to recover the memory of the hydrogeological system's functioning, which has vanished from the general knowledge pool of Quito's citizenship.

This recovery process will not be conservative in the traditional sense of a recovery of ravines as they existed in the past. Similarly, it will not be a superficial, architectural cover up through a frivolous level of vegetation. The proposal suggests recovering the transformative aspect of memory through operations that not only work on an architectural scale, but also propose urban-scale transformations to increase filled ground's permeability at patrimonial locations.

All this defines a transformative, active memory, that foresees the inclusion of future operations that define a manual of good practices for protection-based - rather than conservation-based - development.

HCQ is a high-risk location, from a social, environmental, urban and architectural perspective. Therefore, it is necessary and essential to undertake:

1. Detailed inventories of the technical constructive state of those patrimonial buildings made with raw earth which could be affected by capillary moisture. Those buildings located in the influence area of filled ravines within the perimeter of the World Heritage Site area should be prioritised.

2. Detailed inventories about modifications and current state of DMQ's ravines, with special attention to the functioning state and deterioration of the sewage system. A detailed analysis of HCQ's situation will also take place, given the undeniable importance of the state of raw earth edifications with high patrimonial value within the World Heritage Site area.

3. An inventory of existing interstitial spaces associated to the ravines' path within the World Heritage Site area. They are considered possible areas of intervention that lead to a transformation of the future city from a passive memory towards an active memory.

4. A rescue of Memory in relation to the ravines within HCQ as an active operator for future transformative provisions associated to the social, environmental, urban and architectural dimensions.

5. Considering a "Manual of Good Practice" for the future planning of HCQ. This document would assume active memory as an operator of innovation and stimulation of current and future transformations of a territory with internationally recognised patrimonial value.

6. Visibilize the consequences of the closure of HCQ's ravines at an urban level.

\section{REFERENCES}

Calderón, L., 2015. La construcción tradicional y su vulnerabilidad sísmica "el caso de Quito y sus construcciones con valor patrimonial. Congreso CONPAT, Lisboa, Portugal 
Calderón, L., 2017. Patología de la construcción en tierra cruda en el área andina ecuatoriana. AUC revista de arquitectura, 38, p.31-41,http://editorial.ucsg.edu.ec/ojs-auc/index.php/aucucsg/article/view/69

Carrión, F., 2009. El centro histórico como objeto de deseo. In F. Carrión y L. Hanley (ed.). Regeneración y revitalización urbana en las Américas: Hacia un estado estable, p. 35-57. FLACSO- E / USAID, Quito.

Chávez Pullas, V., 2014. Plan de rehabilitación de las tuberías matrices y pozos de inspección de alcantarillado de la subcuenca alta del colector sucre - sector centro histórico de quito. Proyecto de Titulación, PUCE, Quito, Ecuador.

Corboz, A., 1983. Le territoire comme palimpseste. Diogène, 121, p. $14-35$

Cruz Cabrera, M., 2017. Espacios públicos como áreas sensibles en el Centro Histórico de Quito. Revista EIDOS, 10, ISSN 1390-5007

D’Ercole, R., Metzger, P., \& Villamar, M., 2004. La vulnerabilidad del distrito metropolitano de Quito. Municipio del Distrito Metropolitano de Quito, Dirección Metropolitana de Territorio y Vivienda, Quito, Ecuador.

Delgado Amaya, Cristian R., 2016. Parámetros para la elaboración del Manual de Fiscalización para edificaciones patrimoniales en la ciudad de Quito. Proyecto de Titulación, PUCE, Ecuador.

ECCO Distrito Metropolitano de Quito, 2011. Perspectivas del ambiente y cambio climático en el medio urbano. www.flacsoandes.edu.ec

Edgar Romero G. RT, 2018. Quito, la primera ciudad del mundo en ser declarada Patrimonio Cultural de la Humanidad. Publicado: 8 sept 2018 10:07 GMT

Hazen \& Sawyer., 2011. Estudios de actualización del plan maestro integrado de agua potable y alcantarillado para el distrito metropolitano de Quito. Resumen Ejecutivo. Empresa Pública Metropolitana de Agua y Saneamiento de Quito. EPMAPS, Quito, Ecuador.

INAMHI., 2015. Datos climaticos del DMQ 200-2012. INAMHI,Quito, Ecuador.

Istituto Metropolitano del Patrimonio IMP., 2018b. Diagnóstico Centro Histórico de Quito. IMP, Quito, Ecuador.

Jaramillo, Sofía., 2013. Quito y sus recorridos de agua Abastecimiento, discursos y pautas higiénicas modernizantes. Luzuriaga Universidad Andina Simón Bolívar.

Maximy, R., Peyronnie, K., 2002. Quito Inesperado. De la memoria a la mirada crítica. Instituto Francés de estudios andinos, Abya-Yala, Quito.

MDMQ., UNESCO., 2018. Plan de gestión del riesgo de desastres para el núcleo central del centro histórico de quito, patrimonio mundial. MDMQ, Quito, Ecuador.

Ortiz Crespo, A., 2004. Origen, traza, acomodo y crecimiento de la ciudad de Quito. Trama, Quito.
Peltre, P., 1989. Quebradas y riesgos naturales en Quito, periodo 1900-1988. In Riesgos naturales en Quito, p. 45-66. Corporación Editora Nacional, Quito.

Peñaranda, L., 2011. Manual para la conservación del patrimonio arquitectónico habitacional de Sucre. Conservando nuestro patrimonio.

Pino Martínez, I., 2017. Espacio urbano en la historia de Quito: territorio, traza y espacios ciudadanos. Tesis de Doctorado, Universidad Nacional de Colombia, Bogotá, Colombia.

Salazar, D., Demoraes, F., Bermúdez, N., Zavgorodniaya, S., 2009. De Trébol a girasol: consecuencias de un hundimiento ocurrido el 31 de marzo de 2008 en un eje esencial de la red vial de la ciudad de Quito. Bulletin de l'Institut français d'études andines, 38 (3), doi.org/10.4000/bifea.2360

Serie Quito., 1990. Centro histórico de Quito: Problemática y perspectiva. Trama, Quito, Ecuador.

Serie Quito., 1991. Centro Histórico de Quito: La Vivienda. Trama, Quito Ecuador.

Sierra, A., 1997. Metodología de análisis de los Espacios de Riesgo en el Medio Urbano: EI ejemplo de las quebradas de Quito. In Zavgorodniaya de Costales, S. (ed). Geografía y medio ambiente, 10-20. Corporación Editora Nacional, Colegio de Geógrafos de Ecuador, Quito.

Sierra, A., 2000. Gestion et enjeux des espaces urbains à risque d'origine naturelle: les versants et les quebradas de Quito, Ecuador. Thèse de doctorat, Universitè de Paris - Vicennes Saint-Denis, Paris, France.

Sierra, A., 2009. La política de mitigación de los riesgos en las laderas de Quito: ¿qué vulnerabilidad combatir?. Bulletin de l'Institut français d'études andines, 38 (3), DOI: 10.4000/bifea.2421

UNESCO., 2011. Recomendación sobre el paisaje urbano histórico, con inclusión de un glosario de definiciones. Instrumentos normativos. http://portal.unesco.org/es/ev.phpURL_ID=48857\&URL_DO=DO_TOPIC\&URL_SECTION=20 1.html

Villagómez, D., 2003. Evolución geológica Plio-Cuaternaria del Valle Interandino Central del Ecuador (zona de Quito Guallabamba - San Antonio). Proyecto de Titulación, EPN, Quito, Ecuador.

Zevallos, O., Romo, M., Vallejo, R., 2010. ...en las faldas inmensas de un monte...Las laderas occidentales de la ciudad de Quito. Municipio del DMQ, Quito, Ecuador. 